\title{
PEMAHAMAN TEORI DATA WAREHOUSE BAGI MAHASISWA TAHUN AWAL JENJANG STRATA SATU BIDANG ILMU KOMPUTER
}

\author{
Harco Leslie Hendric Spits Warnars ${ }^{1 *}$, Epafras Suria ${ }^{1}$, Darren Kent Jeremy ${ }^{1}$ \\ ${ }^{1}$ Surya University \\ Curug Sangereng, Kelapa Dua, Tangerang, Banten \\ Email: spits.warnars@surya.ac.id, epafras90suria@gmail.com, darren.kentjeremy@yahoo.com \\ *Penulis korespondensi
}

\begin{abstract}
Abstrak: Sebagai seorang lulusanilmu komputer, mahasiswa ilmu komputer wajib menguasai teori database sebagai sebuah konsep pengelolaan data. Database dibutuhkan dalam segala bidang kehidupan manusia yang merupakan implementasi ilmu komputer, seperti sistem informasi, teknologi informasi, internet, game, kecerdasan tiruan, robotik dan lain-lain. Tak pelak lagi, pengelolaan dan penanganan data yang tepat akan menghasilkan sebuah implementasi teknologi yang handal. Data Warehouse sebagai salah satu mata kuliah peminatan yang ditawarkan pada semester akhir pada program studi ilmu komputer memberikan tantangan tersendiri bagi mahasiswa ilmu komputer. Survey yang dilakukan terhadap 18 mahasiswa program studi ilmu komputer tahun awal pada universitas Surya memberikan hipotesa bahwa bagi mahasiswa yang pernah mendengar tentang data warehouse akan tertarik mempelajari data warehouse sementara mahasiswa yang belum pernah mendengar tentang data warehouse akan tidak tertarik untuk mempelajari data warehouse. Oleh karena itu penting kiranya penyampaian materi kuliah data warehouse dikuasai dengan baik oleh dosen, sehingga mahasiswa dapat memahami data warehouse.
\end{abstract}

Kata kunci: Data warehouse, database, ilmu komputer, perguruan tinggi

\begin{abstract}
As a Computer scientist, a computer science students should have understanding about database theory as a concept of data maintenance. Database will be needed in every single human real life computer implementation such as information systems, information technology, internet, games, artificial intelligence, robot and so on. Inevitably, the right data handling and managament will produce excellent technology implementation. Data warehouse as one of the specialization subject which is offered in computer science study program final semester, provide challenge for computer science students.A survey was conducted on 18 students of early year of computer science study program at Surya university and giving hypothesis that for those students who ever heard of a data warehouse would be interested to learn data warehouse and on other hand, students who had never heard of the data warehouse will not be interested to learn data warehouse. Therefore, it is important that delivery of the Data warehouse subject material should be understood by lecturers, so that students can well understoodwith the data warehouse.
\end{abstract}

Keywords: Data warehouse, database, computer science, higher education

\section{PENDAHULUAN}

Program studi ilmu komputer sebagai salah satu pilihan program studi favorit yang terdiri dari pilihan program studi seperti teknik informatika, teknologi informasi dan sistem informasi masih banyak diminati oleh calon mahasiswa strata satu. Hal ini dibuktikan sebagaimana yang ditampilkan grafik lingkaran pada gambar 1, dimana program studi ilmu komputer diminati oleh calon mahasiswa strata satu, menempati posisi ke 3 sebanyak 13\% dengan jumlah 97.775 dari 776.934 calon mahasiswa pada peserta SNMPTN (Seleksi Nasional Masuk Perguruan Tinggi Negeri) tahun 2014[1].

Varian mata kuliah yang ditawarkan pada program studi ilmu komputer sebagian besar terdiri dari mata kuliah yang mengarahkan mahasiswa untuk menjadi seorang ahli komputer yang dapat mempunyai beragam peminatan diantaranya sistem kecerdasan tiruan, sistem informasi, Embedded System, game dan lain-lain.

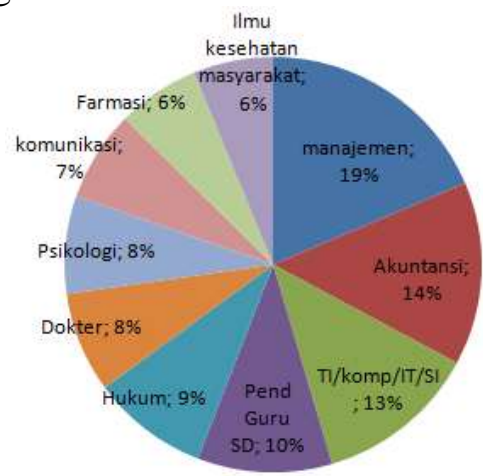

Gambar 1. Grafik lingkaran 10 program studi favorit peserta SNMPTN 2014. 
Latar belakang mahasiswa yang kebanyakan tidak mendapat materi ilmu komputer pada pendidikan sekolah menengah atas memberikan tantangan tersendiri bagi mahasiswa. Mata kuliah khusus pada ilmu komputer seperti sistem perangkat lunak, database, jaringan komputer, bahasa pemrograman, teknologi informasi dan varian mata kuliah lainnya untuk teknologi internet, game dan robotik merupakan fondasi mata kuliah ilmu komputer yang harus dikuasai oleh mahasiswa peminat ilmu komputer. Dalam hal ini, dibutuhkan keseriusan dan ketekunan mahasiswa untuk mempelajari mata kuliah khusus ilmu komputer ini termasuk mata kuliah tambahan lainnya yang mendukung karakteristik peminatan mahasiswa seperti aljabar linier, kalkulus, Fisika, Kimia, bahasa, agama, pancasila, budi pekerti dan lain-lain.

Implementasi dan penerapan ilmu komputer pada bidang kehidupan manusia seperti kecerdasan tiruan, sistem informasi, teknologi informasi, internet, robotik, internet, game dan lain-lain, tak pelak lagi membutuhkan pengelolaan dan penanganan data yang benar dalam rangka menerapkan aplikasi komputer yang handal. Pengelolaan dan penanganan data yang benar akan menghasilkan penerapan teknologi komputer yang handal dan sebaliknya pengelolaan dan penanganan data yang salah akan mengurangi daya guna dari aplikasi teknologi komputer yang dikembangkan. Database sebagai teknologi pengelolaan data pada bidang ilmu komputer, tak pelak lagi wajib untuk dikuasai oleh mahasiswa ilmu komputer. Seorang lulusan ilmu komputer wajib untuk memahami dan menguasai teori database didalam rangka pengelolaan dan penanganan data yang baik dan benar guna mendapatkan sebuah aplikasi penerapan teknologi komputer yang handal.

\section{SURVEY PEMAHAMAN DATA WAREHOUSE}

Data Warehouse sebagai bagian dari teknologi database, merupakan pemahaman dan penerapan teknologi database tingkat lanjut. Data Warehouse akan mudah dipelajari setelah mahasiswa mendapatkan pengajaran tentang dasar-dasar teknologi database. Data Warehouse merupakan kelanjutan dari konsep normalisasi model database yang menggunakan model database normal untuk penerapan proses transaksi harian yang bebas dari pengulangan data dan mempunyai banyak tabel database. Sedangkan data warehouse merubah model database normal menjadi tidak normal yang menyebabkan terjadinya pengulangan data dan berkurangnya jumlah tabel database yang pada akhirnya akan meningkatkan performa aplikasi teknologi komputer [12].

Oleh karena data warehouse akan lebih mudah dipelajari jika telah mempelajari mata kuliah database, maka pemahaman data warehouse akan menjadi tantangan bagi mahasiswa ilmu komputer tahun awal, dimana mata kuliah database diberikan pada semester ke 3 atau 4. Untuk itu sebuah survey dilakukan untuk menjaring pendapat mahasiswa strata satu tahun awal pada bidang ilmu komputer pada program studi HCI (Human Computer Interaction) universitas Surya. Survey dilakukan dengan tujuan untuk mengetahui pendapat dan pengetahuan mahasiswa ilmu komputer tahun awal tentang data warehouse. Survey dibuat dengan menggunakan google Forms dan mengirim link survey ke group facebook mahasiswa program studi komputer dan sampel data dijaring selama 1 minggu mulai tanggal 20 Januari 2015 hingga 27 Januari 2015. Adapun pertanyaan survey terdiri dari:

a. Apakah pernah mendengar tentang istilah data warehouse?

b. Jika menjawab pertanyaan pertama ya, maka dari sumber mana istilah data warehouse diketahui?

c. Jika menjawab pertanyaan pertama ya, sejak kapan istilah data warehouse diketahui?

d. Apa yang anda ketahui tentang data warehouse?

e. Apakah anda tertarik mempelajari data warehouse?

Survey diisi oleh 18 mahasiswa tanpa membedakan jenis kelamin dan usia dari total 111 mahasiswa angkatan tahun ke 1 dan 2 program studi ilmu komputer universitas Surya, maka sampel yang digunakan adalah $18 / 111 * 100 \%=16.22 \%$. Berdasarkan hasil survey, ada 5 mahasiswa yang menjawab ya dan 13 mahasiswa yang menjawab tidak untuk pertanyaan a. Gambar 2 memperlihatkan prosentase hasil survey dengan jumlah responden 18 mahasiswa yaitu ada 5 responden atau $5 / 18 * 100 \%=28 \%$ yang pernah mendengar tentang istilah data warehouse dan ada 13 responden atau $13 / 18 * 100 \%=72 \%$ yang belum pernah mendengar istilah data warehouse.

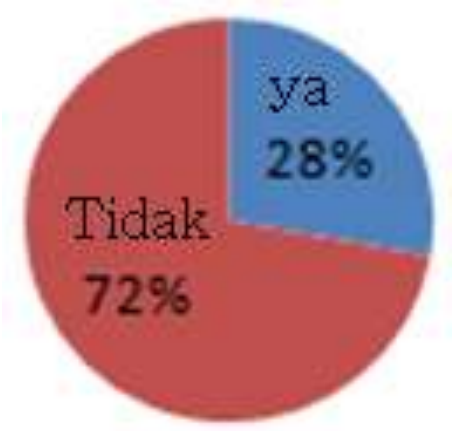

Gambar 2. Grafik lingkaran prosentase hasil survey pertanyaan a dengan jumlah responden 18 mahasiswa. 
Sementara itu, gambar 3 memperlihatkan prosentase hasil survey dengan jumlah total 111 mahasiswa yaitu ada $5 / 111 * 100 \%=4 \%$ mahasiswa yang pernah mendengar tentang istilah data warehouse dan ada $13 / 111 * 100 \%=12 \%$ mahasiswa yang belum pernah mendengar istilah data warehouse.

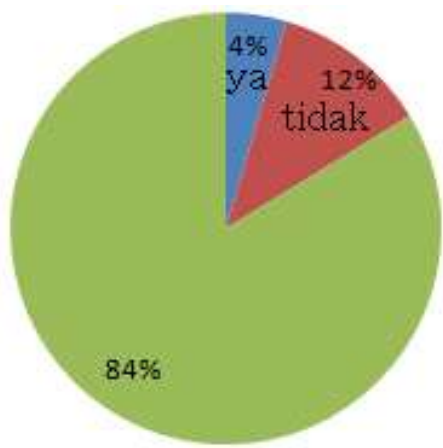

Gambar 3. Grafik lingkaran prosentase hasil survey pertanyaan a dengan jumlah total 111 mahasiswa.

Sementara itu, pertanyaan $\mathrm{b}$ dijawab oleh 6 mahasiswa yang mana 3 mahasiswa mendapat informasi dari dosen sementara 3 mahasiswa lain mendapat informasi dari internet. Lebih lanjut, pertanyaan c juga dijawab oleh 6 mahasiswa dimana ke 6 mahasiswa ini mengetahui tentang istilah data warehouse sejak kuliah di program studi ilmu komputer.

Menariknya, untuk pertanyaan d yang dijawab oleh 6 mahasiswa memperlihatkan kurang pemahaman mereka tentang data warehouse. Berikut merupakan jawaban ke 6 mahasiswa untuk pertanyaan d yaitu:

- Tempat menyimpan kumpulan data.

- sebuah sistem mandiri yang terprogram untuk menympan data, mengatur dan mengirimkan untuk diambil keputusan.

- Sebuah database yang menyimpan sekumpulan data.

- Gudang data yang isinya ada banyak data yang dapat diolah untuk maksud dan tujuan tertentu.

- penyimpanan data dimana datanya bisa kita tambah, ubah, kurangi.

- kalau tidak salah data warehouse merupakan suatu sistem komputer untuk mengarsipkan dan menganalisis data historis suatu organisasi.

Untuk pertanyaan survey e, ada 13 mahasiswa yang menjawab ya dan kebalikannya ada 5 mahasiswa yang menjawab tidak. Gambar 4 memperlihatkan prosentase hasil survey dengan jumlah responden 13 mahasiswa responden yaitu ada $13 / 18 * 100 \%=72 \%$ yang tertarik untuk mempelajari data warehouse dan kebalikannya ada 5 mahasiswa responden atau $5 / 18 * 100 \%=28 \%$ yang tidak tertarik untuk mempelajari data warehouse.

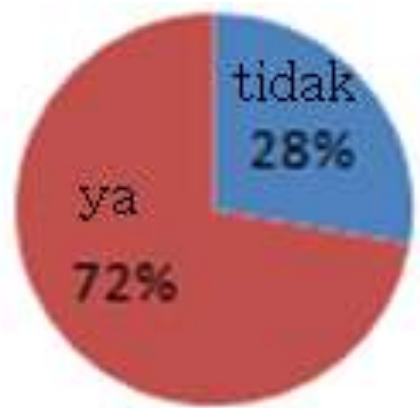

Gambar 4. Grafik lingkaran prosentase hasil survey untuk pertanyaan e dengan jumlah responden 18 mahasiswa.

Sementara itu, gambar 5 memperlihatkan prosentase hasil survey dengan jumlah total 111 mahasiswa yaitu ada $13 / 111 * 100 \%=12 \%$ yang tertarik untuk mempelajari data warehouse dan kebalikannya ada 5 mahasiswa atau $5 / 111 * 100 \%=$ $4 \%$ mahasiswa responden yang tidak tertarik untuk mempelajari data warehouse.

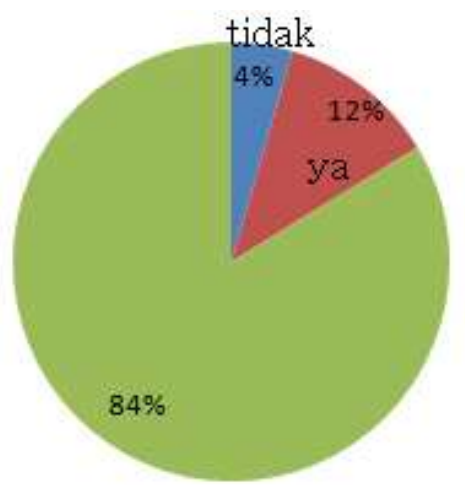

Gambar 5. Grafik lingkaran prosentase hasil survey untuk pertanyaan e dengan jumlah total 111 mahasiswa.

Menariknya, berdasarkan pertanyaan survey e, ke 5 mahasiswa yang tidak tertarik mempelajari data warehouse ini menjawab tidak untuk pertanyaan a dimana mereka tidak pernah mendengar istilah data warehouse. Berarti ini menjadi peluang bahwa semua mahasiswa sample $(18 / 18 * 100 \%=100 \%)$ berminat untuk mempelajari data warehouse. Ke 5 mahasiswa tersebut tidak berminat untuk mempelajari data warehouse karena mereka tidak pernah mendengar istilah data warehouse. Seandainya mereka pernah mendengar istilah data warehouse maka mereka akan tertarik mempelajari data warehouse seperti ke 5 mahasiswa yang menjawab ya untuk pertanyaan a yaitu pernah mendengar tentang data warehouse, menjawab ya untuk pertanyaan e yaitu tertarik mempelajari data warehouse.

Berdasarkan analisa data tersebut, maka berikut hipotesa yang terbentuk: Mahasiswa Program Studi Ilmu Komputer Universitas Surya yang pernah mendengar tentang data warehouse akan tertarik mempelajari data warehouse sementara mahasiswa 
yang belum pernah mendengar tentang data warehouse tidak tertarik untuk mempelajari data warehouse.

Namun hipotesa ini patut perlu diuji, mengingat berdasarkan data sebuah survey terhadap tingkat kesulitan mata kuliah yang ditawarkan pada program studi Teknik Informatika, universitas Stikubank menunjukkan mata kuliah data warehouse adalah mata kuliah yang paling tersulit dengan prosentase $50 \%$ dari jumlah seluruh responden dari 50 mahasiswa[6]. Oleh karena itu, dosen sebagai ujung tombak pembeajaran diharapkan dapat menguasai materi yang akan disampaikan dan menyusun rencana dan strategi pembelajaran mata kuliah[6]. Materi mata kuliah data warehouse perlu disusun sesuai dengan yang diimplementasikan di masyarakat, dimana mahasiswa bisa mendapat contoh aktual penerapan data warehouse, yang mana akan memberi manfaat kepada universitas dan dunia kerja selain mahasiswa itu sendiri [8].

Berdasarkan hipotesa diatas, maka ketertarikan mahasiswa untuk dapat lebih meyakinkan mendalami teori data warehouse dapat dipertajam dengan menggunakan bantuan teknologi informasi. Data mining dapat diimplementasikan guna memprediksi tingkat peminatan mahasiswa dalam mempelajari mata kuliah data warehouse. Teknik clustering pada data mining digunakan untuk pengelompokan pemilihan mata kuliah pilihan di semester akhir berdasarkan nilai mata kuliah sebelumnya, dimana pengelompokkan ini menjadi pertimbangan bagi mahasiswa dan manajemen terkait mata kuliah pilihan mana yang akan diambil [2]. Clustering dilakukan pada 3 peminatan mata kuliah pilihan yaitu teknologi basis data, sistem pendukung manajemen dan sistem informasi akuntansi dengan menggunakan aplikasi WEKA dan database SQL Server 2008 yang menggunakan algoritma K-Means dan EM (Expectation Maximization) [2].

\section{PENGALAMAN PENYAMPAIAN MATERI KULIAH DATA WAREHOUSE PADA PER- GURUAN TINGGI}

Untuk mempertajam tingkat kemampuan dosen dalam mengajar data warehouse dan mempermudah mahasiswa dalam memahami data warehouse, maka fungsi laboratorium database dapat ditingkatkan melalui akses online internet yang dapat diakses oleh mahasiswa dan dosen kapan sajadan dimana saja. Mahasiswa dan dosen dimudahkan dalam membuat dan membangun sebuah data warehouse dan menjalankan perintah SQL (Structured Query Languages) dan sebuah OLAP (Online Analytical Processing) dapat dibangun dan fungsi multi- dimensional pada data warehouse dapat dijalankan dengan melakukan roll-up, drill-down dan slice-dice proses [10]. Namun untuk dapat meningkatkan pemahaman mahasiswa tentang data warehouse dan penguasaan dosen dalam mengajar, maka penggunaan lab database online internet ini harus dijalankan bersamaan dengan lab yang manual [10].

Sementara itu, jurusan Teknik Informatika universitas DR. Soetomo Surabaya, membuat sebuah prototipe datawarehouse untuk pembelajaran teori data warehouse untuk mahasiswa jurusan Teknik Informatika[3]. Prototipe datawarehouse dilakukan dengan mendesain 3 star schema untuk informasi IPS (Indeks Prestasi Sementara) mahasiswa, informasi rata-rata kelas dan informasi kehadiran dosen, yang datanya di ETL (Extraction Transformation and Loading) dari database akademik universitas. Ke-3 star schema tersebut diimplementasikan dengan menggunakan Microsoft SQL server 2005, yang secara keseluruhan mempunyai 3 table fakta dan 7 table dimensi. Sementara itu untuk implementasi OLAP (Online Analytical Processing) menggunakan Microsoft SQL server Analysis Service 2005. Video sebagai alat pembelajaran visual digunakan untuk mempelajari implementasi data warehouse, dimana video memperlihatkan bagaimana membuat sebuahBusiness intelligence projects pada Microsoft visual studio [11].

\section{PENGALAMAN PENYAMPAIAN MATERI KULIAH DATA WAREHOUSE PADA PRO- GRAM STUDI NON ILMU KOMPUTER}

Selain itu, data Warehouse tidah hanya diajarkan pada program studi ilmu komputer namun merambah ke program studi lainya, sebagai contoh materi bisnis intelijen diajarkan pada program studi keuangan pada mata kuliah perbankan [5]. Konsep OLAP (Online Analytical Processing) yang merupakan implementasi data warehouse diterapkan dengan pendekatan multidimensional, dimana data dapat ditampilkan dari berbagai sisi data. Pada program studi bisnis strata 1 , materi mata kuliah bisnis intelijen diajarkan dengan cara menarik dan menyenangkan dengan menggunakan framework yang diebut "real life puzzles", dimana setiap "puzzle" terdiri dari masalah nyata sehari-hari, data nyata sehari-hari dan solusi nyata sehari-hari[7]. Selain itu survey dilakukan terhadap 10 dosen pengajar mata kuliah bisnis intelijen pada universitas di Inggris baik untuk sarjana ataupun magister mengarahkan bahwa contoh data nyata sehari-hari baik untuk dimengerti oleh mahasiswa dan kesiapan dosen dalam mengajar juga menjadi bagian yang penting [9]. 
Lebih lanjut, data warehouse dibutuhkan untuk diajar pada program studi statistik jenjang strata 1 , pada study kasus dari 7 institusi yaitu Johns Hopkins University, Purdue University, St. Olaf College, Smith College, University of Auckland, and the Universities of California, Berkeley and Davis) [4]. Ketujuh institusi ini disurvey tentang bagaimana pendekatan mereka memadukan ilmu tentang data pada kurikulum statistik. Ketujuh institusi yang disurvey tersebut memiliki kemiripan dalam menciptakan mahasiswa yang ahli menggunakan teknologi dan pemrograman untuk memecahkan kasus yang berhubungan dengan data. Setiap institusi mempunyai pendekatan yang berbeda dalam metode penyampaian, topik dan hasil pembelajaran. Hal yang penting bagi ketujuh institusi tersebut adalah desain, model dan analisa penelitian statistik untuk kurikulum statistik jenjang strata 1 sudah tidak cocok dengan permasalahan data saat ini, dimana data yang dihadapi saat ini adalah data yang sangat besar dan komplek sehingga implementasi komputer dibutuhkan disini [4].

\section{KESIMPULAN}

Data warehouse sebagai mata kuliah pada semester akhir akan menjadi kesulitan tersendiri bagi mahasiswa untuk mempelajarinya, namun dibutuhkan keuletan dan keinginan mahasiswa untuk mempelajarinya. Data warehouse sebagai sebuah mata kuliah lanjutan untuk mata kuliah database, tidak hanya dipelajari pada program studi ilmu komputer. Pengalaman, pengetahuan dan keahlian dosen tentang data warehouse sangat berperan penting, selain didukung oleh aplikasi yang dapat mensimulasikan proses data warehouse dalam melakukan multidimensional proses seperti drill-down, roll-up dan slice-dice.

Data warehouse akan mudah dipelajari oleh mahasiswa yang berminat mempelajarinya dengan menggunakan data-data dan proses bisnis yang nyata dalam kehidupan sehari-hari. Suasana rileks dan menyenangkan dalam proses pembelajaran turut berperan andil meningkatkan minat mahasiswa untuk mempelajarinya.

\section{DAFTAR PUSTAKA}

[1] Nurfuadah, R.N., 2014, "Manajemen, Prodi Terfavorit di SNMPTN 2014", diakses pada tanggal 27 jan 2015 dari: http://news.okezone. com/read/2014/05/26/373/990241/manajemenprodi-terfavorit-di-snmptn-2014.
[2] Mardiani, 2011, Pengelompokan Mata Kuliah Peminatan Mahasiswa Era globalisasi studi kasus sekolah tinggi XYZ, Prosiding Seminar Nasional Pendidikan, Palembang, 27 Juni 2011, pp. 501-511.

[3] Widiartin, T, \& Taufik, 2008, Membangun Prototipe pembelajaran studi Data Warehouse dengan sample Explore Sistem di jurusan Teknik Informatika Universitas DR. Soetomo Surabaya, Jurnal Sistem Informasi Universitas Kristen Maranatha, Vol. 3, No, 2.

[4] Hardin, J., Hoerl, R., Horton, N.J. and Nolan, D., 2014, Data science in the Statistics curricula: preparing students to "Think with Data", arXiv.org, diakses pada tanggal 25 Februari dari :http://arxiv.org/ftp/arxiv/papers/1410/1410.312 7.pdf

[5] Mrdalj, S. \& Diallo, A., 2010, Bringing Business Intelligence into finance curriculum, Issues in Information Systems, Vol. 11, No. 2, pp.168-175.

[6] Handayani, D.U.N. Saefurrohman \& Sunardi, 2009, Analisis proses pembelajaran untuk mata kuliah ilmu komputer bagi mahasiswa teknik informatika, Dinamika Informatika, Vol. 1, No. 2, pp.136-144.

[7] Presthus, W. \& Bygstad, B., 2012, Business Intelligence in College: A teaching case with real life puzzles, Journal of Information Technology Education: Innovations in Practice, Vol. 11, No.1, pp. 121-137.

[8] Taylor, E., 2012, Teaching data warehouses in collaboration with industry: Bridging the expectations gap, International Conference on Information Society (i-Society), Potchefstroom, South Africa, pp. 366-369.

[9] Presthus, W., 2012, Never giving up: Challenges and solutions when teaching Business Intelligence, The $35^{\text {th }}$ Information Systems Research Conference in Scandinavia (IRIS), $17^{\text {th }}-20^{\text {th }}$ August, Sigtuna, Sweden.

[10] Jiangping, W. \& Janet, L.K., 2012, Delivering database knowledge with web-based labs, Proceedings of ASBBS (American Society of Business and Behavioral Sciences), Vol. 19, No.1, pp. 923-931.

[11] Olsen, D.H. \& Bryant, P., 2012, Business Intelligence and Information Systems: Enhancing student knowledge in Database courses, Review of Business Information Systems, Vol. 16, No.1, pp. 1-14.

[12] Vaisman, A. \& Zimanyi, E., 2014, Data Warehouse Systems, Design and implementation, Springer-Verlag. 